
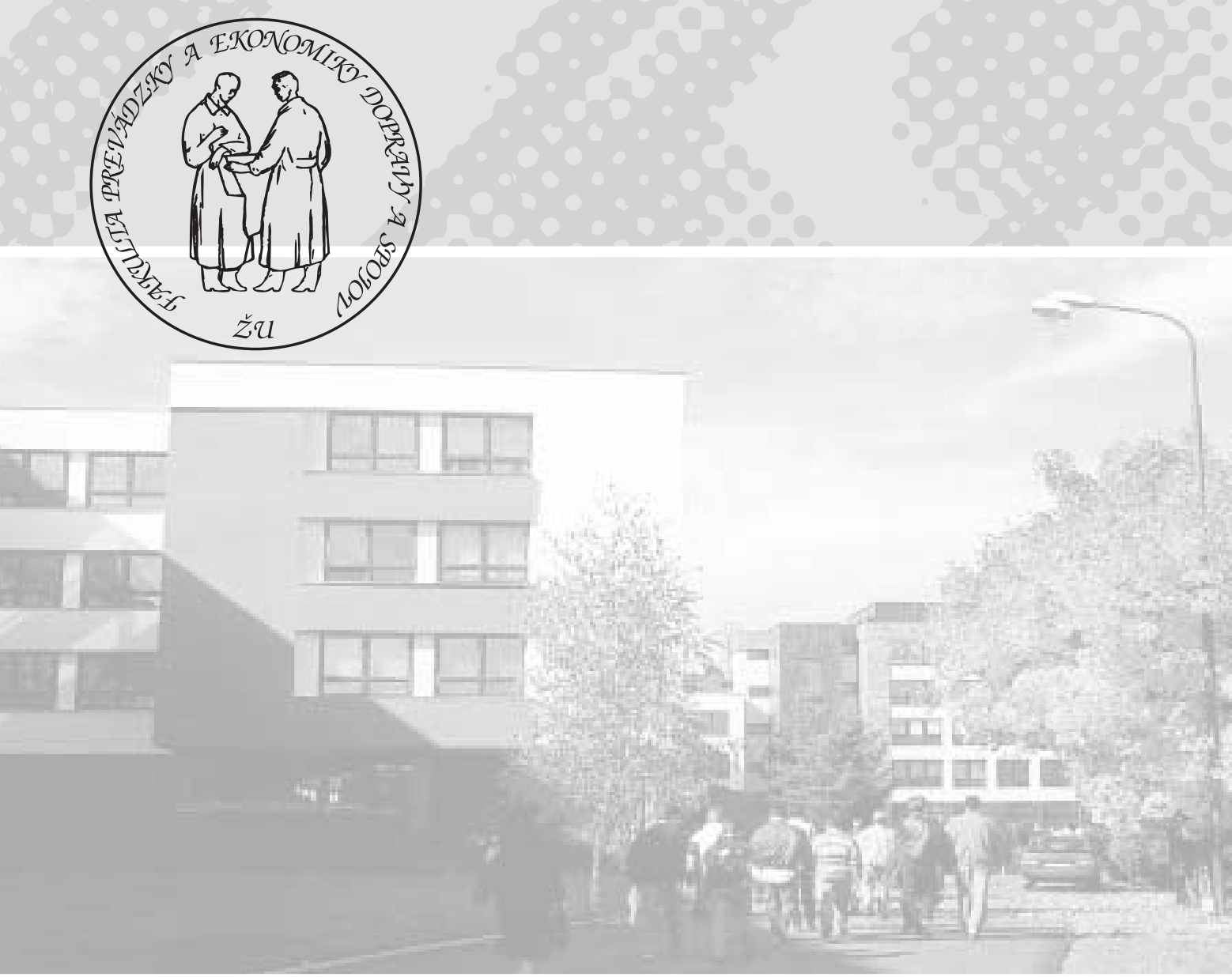

\title{
FACULTY OF OPERATION AND ECONOMICS OF TRANSPORT AND COMMUNICATIONS
}


FACULTY

OF OPERATION

AND ECONOMICS

OF TRANSPORT AND COMMUNICATIONS

\author{
Vel'ký diel NF, 01026 Žilina, Slovakia \\ Phone: +421-41-5133011, Fax: +421-41-5651499 \\ Dean \\ prof. Ing. Tatiana Čorejová, PhD. \\ E-mail: corejova@fpedas.utc.sk \\ Vice-Dean for Foreign Affairs \\ doc. Ing. Luděk Beňo, PhD. \\ E-mail: beno@fpedas.utc.sk \\ Vice-Dean for Education Affairs \\ doc. Ing. Jozef Majerčák, PhD. \\ E-mail: majercak@fpedas.utc.sk \\ Vice-Dean for Research and Development - \\ prof. Ing. Jana Štofková, PhD. \\ E-mail: stofkova@fpedas.utc.sk
}

The Faculty of Operation and Economics of Transport and Communications provides university education and prepares specialists for solution of management, technology, economic problems and for business activities especially in sphere of transport, postal services, telecommunications as well as in sphere of business management and economics, banking industry and three-level education system of banking.

Education and research of the faculty are oriented especially to solution of these problems:

- transport, postal and telecommunication policy and identification of socially optimal level of transport, postal and telecommunication systems,

- solution of technology procedures of several kinds of transport, postal services and telecommunications,

- economics and management of network industries,

- efficiency and quality of network systems especially in transport, postal services and telecommunications,

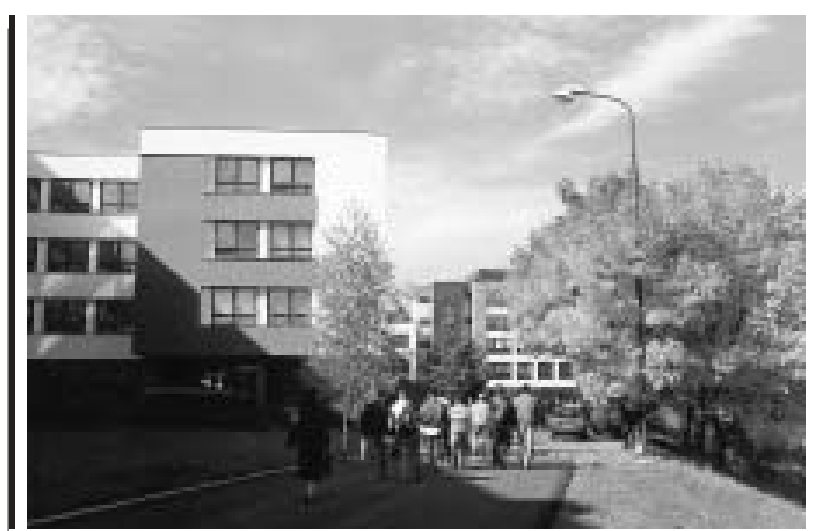

- monitoring of costs in sphere of transport, postal services and telecommunications according to technology and external influences, questions of internalization of external costs,

- application of controlling in infrastructure companies,

- financing of transport, postal and telecommunications projects,

- creating of mass transport systems and appreciation of road mass transport and urban passenger movement,

- demand and supply interactions in transport, postal services, telecommunications and information networks in relation to the market structure and structure of economy,

- diagnosing of business environment in transport, postal services and telecommunications, engineering of suitable diagnostic methods in transport, postal and telecommunications companies and effective settings of therapy in these companies,

- components work motivation structure in networks,

- harmonization and integration of transport operation management systems,

- regional sciences, economies and policies focused to allocation theory of companies, transport and exploitation of territory, economies of public sector, regional dynamics, regional policy and regional integration.

The faculty has the following departments:

- Department of Road and Urban Transport e-mail: kcmd@fpedas.utc.sk

- Department of Air Transport e-mail:srogon@fpedas.utc.sk

- Department of Communications e-mail: ks@fpedas.utc.sk

- Department of Railway Transport e-mail:kovac@fpedas.utc.sk

- Department of Water Transport e-mail:zarnay@fpedas.utc.sk

- Department of Economics e-mail: ksv@fpedas.utc.sk

- Department of Mathematics e-mail: balint@fpedas.utc.sk 


\section{DIAGNOSTIC APPROACH IN PROCESS ENHANCEMENT IN POSTAL SERVICE}

Diagnostics and measurement of the quality are the basis of measures as for efficiency improvement of the whole postal technological system in connection with customers' expectations as well as competition and regulator behaviour. The quality diagnosing can be defined as a process of search and analysis concerning the quality problems and their reasons. The diagnostic approach in postal service involves several process steps, namely the following ones: definition of normality limits (a fixed limit can be replaced by an allowable interval), normal behaviour definition of an object of diagnostics within the normality limits, ability to change or influence the behaviour of the object of diagnostics - of a process or activity.

The effectively and systematically applied diagnostics in postal service is a very useful tool, provided we are able to properly qualify the connections, by which abnormality problems arise and provided we are able to properly identify the main problems in the technological system of postal activities and processes.

In order to develop knowledge in the quality diagnosing in postal service, the staff from the Department of Communications (Faculty of Operation and Economics of Transport and Communications, University of Žilina) solved several scientific and research projects - the grant tasks VEGA Nos. 1/5270/98, 1/8336/01, $1 / 9357 / 02$ as well as projects within business activity, where the particular techniques and methods of the quality diagnosing concerning the transport of items were proved. Getting to know the hierarchical system of quality indicators in postal service was one of the problems and results that were solved.

It is necessary to understand the postal diagnostic system as the hierarchical system with the four following intersecting levels: - The level of the whole establishment, which involves the diagnosing support by creating the quality policy and objectives in postal service and by detecting the problems during their performance.

- The departmental level. The object of diagnostics is decomposed from the level of the whole establishment into the level of particular departments. The functional view of passing phenomena is used.

- The level of processes which pass through the departments in a postal service horizontally, vertically as well as diagonally.

- The level of quality diagnosing concerning particular postal products where data relating to a specific postal product and its values of quality criteria are processed.

The pyramid of indicators for quality diagnostics in a postal service is shown in figure 1.
The achieved results in solving the projects meaningfully contribute to knowledge development in the sphere of improving diagnostics of macro-, mezzo-, and microenvironment in transport of items by post offices. New theoretical knowledge in the quality diagnosing in transport of items, in trend of change as for the quality parameters during the transport of items, and furthermore in the sphere of determining factors which affect the quality of transport of items and their incorporation in quality management systems was obtained.

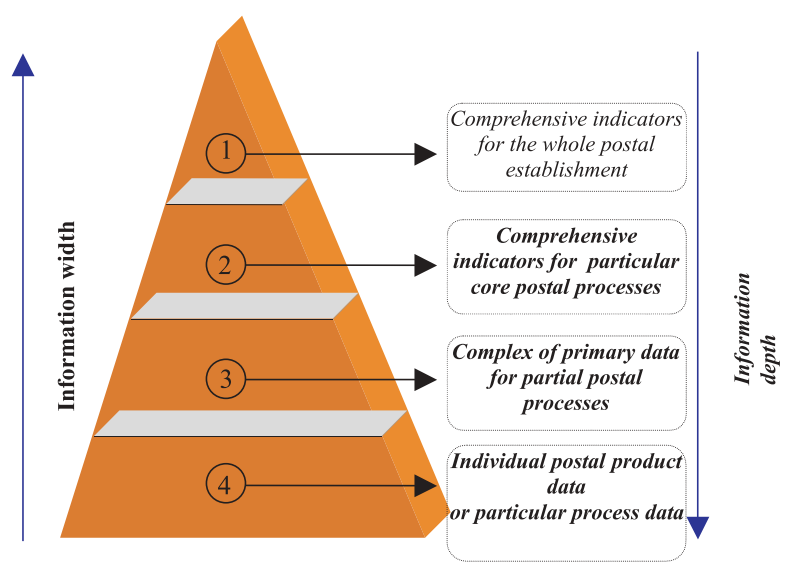

Fig. 1 Pyramid of the indicators for quality diagnostics in postal service.

References:

[1] ČOREJOVÁ, T. et al.: Tools for diagnosing of environment in postal services. In: Final report of project VEGA 1/5270/98, Žilina, 2000

[2] ČOREJOVÁ, T. et al.: Methods for diagnosing of quality in postal services. In: Report of project VEGA 1/8336/01, Žilina, 2002

[3] KREMEŇOVÁ, I. et al.: Investigation of postal operators productivity increasing on the EFQM basis. In: Report of project VEGA 1/9357/02, Žilina, 2002

[4] ACHIMSKÝ, K. et al.: End-to-end measuring transit time - 1st class letters, ordinary letters, postal money orders. In: Projects 1998, 1999, 2000, 2001, F PEDaS, Žilina 


\section{MEASURING METHODOLOGY FOR REAL BUS-STOP DISTANCES OF MASS PASSENGER TRANSPORT LINES}

Request for measuring the real mass passenger transport lines distances originates from the Act of the National Council of the Slovak Republic No. 168/1996 Coll., on the Road Transport (Article 13, par.2) and the Decree of the Ministry of Transport, Posts and Telecommunications of the Slovak Republic No 311/1996. Coll., (Article10 par. 3), implementing the Act of the National Council of the SR. The measurement shall be carried out in compliance with the text of the Act of the National Council of the SR No 142/2000 Coll., on metrology and amendment to some acts (Article 20, par. 2). It should be mentioned, however, that any measuring methodology has not been elaborated in the Slovak Republic yet and this legislation has solved this problem generally only, which caused a great number of conflicts, even law-suits [3]. The measuring methodology for real bus-stop distances of mass passenger transport lines has been elaborated by the Road and Urban Transport Department staff

This methodology gives the principles and procedures for measurement of real distances between bus-stops of mass passenger transport lines, the results of which constitute the basis for determination of tariff distances between the bus-stops on the transport lines. The tariff distance is the basis for calculation of basic passenger fare, payment for carriage of luggage, domestic animals and bus consignments. The methodology is important for the acknowledgement of public service performances.

The methodology No 02/2002/KCMD [1] is generally valid and after its validation by the Ministry of Transport, Posts and Telecommunications on 21. 2. 2002 can be used only by the persons authorised by this body for carrying out the specified activity. This methodology links up the "Measuring methodology for distances by the measurement and reporting instrument Correvit", which was also elaborated by the Road and Urban Transport Department staff and validated by the Slovak Metrological Institute on 20. 2 . 2002 [2]. The operating principle of the CORREVIT system is illustrated by Figure 1.

The main part of the system CORREVIT is developed by an efficient and precise optical-electronic sensor designed for tasks solutions at measurement of dynamic characteristics of the road transport.

The Sensor $L$ (Fig. 1) serves for measurement of distances. It enables touch-less scanning of the vehicle's speed in the longitudinal direction from 0.5 to $200 \mathrm{~km} . \mathrm{h}^{-1}$ with $\pm 0.3 \%$ tolerance and is confirmed by calibrating protocol of the manufacturer.

The operating principle for measurement of longitudinal part of a vehicle speed is the following. The road surface (1), which is a "measuring object", is illuminated by an optical path of rays from the source of light (2) with a $50 \mathrm{~W}$ bulb. The picture of measuring object (illuminated part of the road surface) is transferred by reflected union beams of light through the optical system (3) on the prism grating (4) in which it is collected on two photo-electric detectors - photons (5).

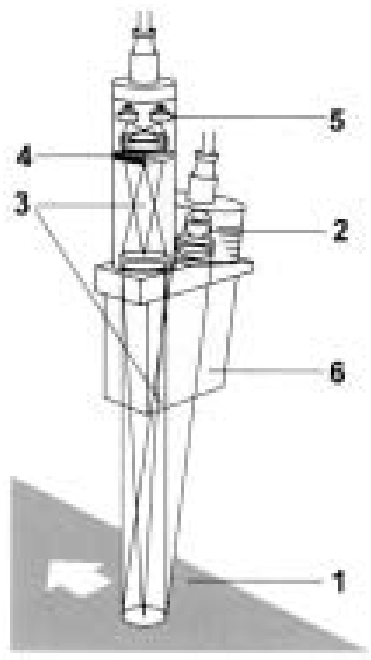

Fig. 1 Optical-electronic Sensor L

The staggered signals generated by the detector are identical apart from a phase displacement of $180^{\circ}$ in their modulation component. The push-pull components can be separated from the lowfrequency common-mode components by a differential amplifier and further amplified separately.

Measured data are stored into the memory of the system and possibly recorded on $3^{1} / 2^{\prime \prime}$ diskette. It can be in an arranged or non-arranged data form. The evaluation system by the software mode gives the graphical results visualization or numeric visualization through the internal printer on the plate paper. The evaluation and data processing is made by the hard programs in which it is possible choose measurement steps in advance in combination with the time, track and speed. It is possible to do some complementary mathematical processing with analogue and digital visualized dignities.

The research results are implemented in:

- learning; the system alone enables to simulate the condition for measurement at the Department of Road and Urban Transport 
Laboratory, it enables measurement demonstrations for students and to print the results,

- in practice - the methodology has already been implemented for measurement of bus-stop distances in the mass passenger transport lines: the Slovak Bus Service Nové Zámky, a.s., transport companies Šala, Levice, Šahy, Želiezovce and Komárno, the Slovak Bus Transport Trnava, a.s., the transport company Pieštany and the Urban Mass Transport Trnava.

Nowadays, from the initiative of the Bus Transport Union which integrates all Slovak Bus Service companies in the SR and other companies of bus service, there is a tendency either to integrate the specified methodology or its systemic use in the amended Decree No 311/1996 Coll., implementing the Act on the road transport.

\section{References:}

[1] CAJCHAN, J., GNAP, J.: Metodika merania skutočných vzdialeností zastávok liniek hromadnej osobnej dopravy, č. 02/ 2002/ KCMD, Žilinská univerzita, F-PEDaS, Žilina 2002, 9 s.

[2] CAJCHAN, J., GNAP, J.: Metodika merania vzdialeností meracím a vyhodnocovacim zariadením CORREVIT, č. 01/2002/ KCMD, Žilinská univerzita, F-PEDaS, Žilina 2002, 16 s.

[3] GNAP, J. A KOL.: Ekonomické a kvalitatívne vplyvy implementácie legislatívy EÚ do legislatívy SR v oblasti cestnej dopravy, Projekt VEGA č. 1/8183/01, ŽU v Žiline, F-PEDAS, 2002

\section{METHODS AND TECHNIQUES OF COMPANY DIAGNOSING}

Modern world of business is subject to many changes with incoherent character and they are results of several progressing processes in companies and environment. New business opportunities follow from asymmetric information, motions and changes. Economic science reflects changes of state, significance and utilization of production factors. Attention is shifted to valuation of velocity and intensity of changes by the valuation of individual business subjects and their successfulness. There is enforcing total view and understanding of a company and criteria of its successfulness are based on financial characteristics, characteristics of the company attractiveness, innovation abilities of the company etc.

We are meeting with problems of diagnosing and company therapy along with solution of logistic and controlling questions at international and homeland conferences. Attention of the scientific community is concentrated on methodologies of these disciplines and within the scientific community on practical utilization of individual methods and techniques of business. It results from the strengthening of interdisciplinary approaches to solution of company and business problems. These questions were in the center of attention of various research tasks solved in collaboration with the Faculty of Economics of VŠB-TU Ostrava in the Czech Republic and University of Management in Czestochowa, Poland. One of the results of project is a process of how to make it easier for a diagnostician, manager or consultant to select a method or technique to specify a diagnosis and therapy of the company (see table No 1).

Table 1

\begin{tabular}{|l|l|l|l|}
\hline Phases & Steps & Suitable actions for individual steps & $\begin{array}{l}\text { Example of available methods, techniques } \\
\text { and tools }\end{array}$ \\
\hline Diagnosis & 0 Input & Recognition of change as a difficult process & $\begin{array}{l}\text { Utilization of terms: "chaos" and "trouble" } \\
\text { Use of diagrams } \\
\text { Convene of individual meetings (NGT, } \\
\text { DELPHI) } \\
\text { Creating of model of actual state }\end{array}$ \\
& $\begin{array}{l}\text { Understanding and structuring of change as } \\
\text { a system } \\
\text { Acquirement of other suggestions for change } \\
\text { and possibility of change } \\
\text { 3 Formulation of measure } \\
\text { of aims }\end{array}$ & $\begin{array}{l}\text { Estimate of aims for examined systems } \\
\text { Thinking of aims of the changes } \\
\text { Decision of valuation method of achieved aim }\end{array}$ & $\begin{array}{l}\text { Creating a "tree of aims" } \\
\text { Estimate of priorities of aims of change } \\
\text { Financial or scale expression of achieved aim }\end{array}$ \\
\hline
\end{tabular}




\begin{tabular}{|c|c|c|c|}
\hline Phases & Steps & Suitable actions for individual steps & $\begin{array}{l}\text { Example of available methods, techniques } \\
\text { and tools }\end{array}$ \\
\hline $\begin{array}{l}\text { Suggestion } \\
\text { of therapy }\end{array}$ & $\begin{array}{l}4 \text { Creating of volume of } \\
\text { alternative possibilities } \\
5 \text { Selective modeling } \\
\text { of possibilities }\end{array}$ & $\begin{array}{l}\text { All ideas to develop as complex possibilities } \\
\text { Analysis of wide spread of possibilities } \\
\text { Survey of known aims and possibilities } \\
\text { of business praxis } \\
\text { Specification of most promising possibilities } \\
\text { up to specific details } \\
\text { (what and who is needed, how it will work) }\end{array}$ & $\begin{array}{l}\text { Brainstorming } \\
\text { Talks and investigations } \\
\text { Benchmarking } \\
\text { Diagrams as the easiest models } \\
\text { Analysis of costs and advantages Cash-flow } \\
\text { models } \\
\text { Computer simulations }\end{array}$ \\
\hline $\begin{array}{l}\text { Realization } \\
\text { of therapy }\end{array}$ & $\begin{array}{l}6 \text { Appreciation of } \\
\text { possibilities by defined aims } \\
7 \text { Suggest of strategy of } \\
\text { realization - implementation } \\
8 \text { Realization of planned } \\
\text { changes }\end{array}$ & $\begin{array}{l}\text { Testing of outputs of possibilities in compare } \\
\text { with agreed list of criteria } \\
\text { Selection of preferred possibilities and planning } \\
\text { of way of realization of changes } \\
\text { Creating of teams and sources } \\
\text { Managing of change process } \\
\text { Monitoring of progressing }\end{array}$ & $\begin{array}{l}\text { Creating of easy matrix for comparing of outputs } \\
\text { of its own possibilities } \\
\text { Items up of each possibility according to aims } \\
\text { Looking for possibilities with high level of } \\
\text { reliability } \\
\text { Repeated arbitration of "problem owners" } \\
\text { Creating timetable and responsibility for } \\
\text { realization of individual tasks } \\
\text { Establishment of people connected to process } \\
\text { Assignment of responsibility and competence } \\
\text { Re-recording and change of plans in the case } \\
\text { of necessity (e.g.: analysis of critical path etc.) }\end{array}$ \\
\hline
\end{tabular}

Benefits of the projects solutions are the following:

a. development of knowledge and deepening of theories from a sector of company diagnosing,

b. establishment of criteria for evaluation of "company health",

c. comparison of methods and processes,

d. creation and completion of diagnostic methods for a company diagnosing,

e. utilization of results of pedagogical activities of the department, faculty and University.

\section{Literature:}

[1] ČOREJOVÁ, T. et al.: Tools for diagnosing of external and internal environment of company, Final report of project within the Agreement between the government of the Slovak Republic and Czech Republic about VTS 2000 - 2001; No. 186/134, Žilina 2001

[2] ROSTÁŠOVÁ, M. et al.: Management of changes in conditions of network organizations, VEGA 1/9186/02

[3] STRENITZEROVÁ, M.: Model of "Managing of people sources" process in conditions of huge network companies, POSTPOINT 01, EDIS Žilina 2001

[4] ŠTOFKOVÁ, J.; KAŠTÁNEK, P., ROSTÁŠOVÁ, M., ŠTOFKO, S.: "Finances in postal service and telecommunications I.", EDIS, Žilina, 1999

\section{NEEDS AND CONCEPTION OF RESTRUCTURING AND TRANSFORMATION OF RAILWAYS}

The process of restructuring and transformation of railways has been brought up by the crisis of railway net systems in particular countries. Generally, two following stages are present:

- first stage - disestablishment - denationalization - meaning assignment of state property to another institution, e.g. in our country or eventually in several further post-communist countries to the Fund of national property,
- second stage - privatization.

\section{Statement of needs for restructuring and transformation}

In the frame of a contemporary enterprise and its property several forms of privatization can be implemented, either in the relation towards the enterprise's property as a whole, or in the 
relation to its particular parts, generally with the aim to create independent private-legal subjects.

Presumption for successful privatization is a detailed preparation of the entrepreneur's strategy project. Its main components are designed in the following diagram.

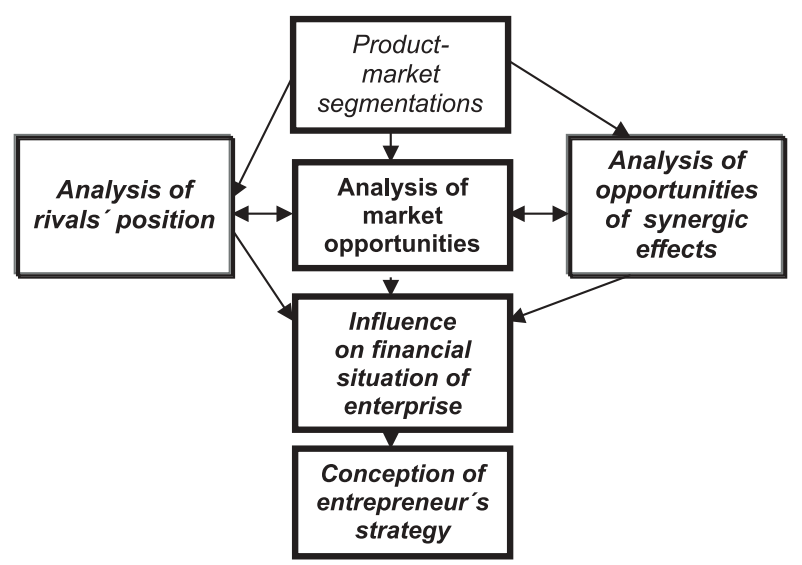

Fig. 1 Preparation of entrepreneurs' strategy

\section{Conceptional problems of privatization and transformation}

Privatization itself deals mainly with the following spheres:

- concentration of financial resources and financial stability

- internal operating co-operation

- optimal exploitation of capacities

- degression of fixed costs

- complexity of service for customers and

- combined execution of advisory and service processes.

The basis for the defining of privatization is the identification of needs of restructuring. Schematic relation between objectives and forms of privatization is presented in the following diagram:

The privatization project should be based on the entrepreneur's intentions which should enable a long-term prosperity of the subject in question. The quality of entrepreneur's goals is of great importance for the process of privatization. The more persuasive prognosis of the expected prosperity, the more quickly a potentional buyer for the whole or for a part of the enterprise's structure both abroad and at home market can be found. When restructuring the parts, it is important to investigate the effects on the whole. In this sphere wrong procedures are very often used. The prosperous parts are sold while the others, having brought mainly negative financial results, are left as a burden to the original organization (state). And if it is a necessary section, the state has to ensure it from its own resources.

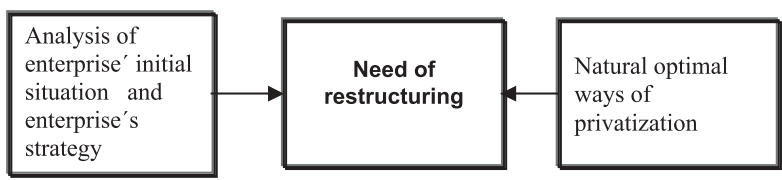

Fig. 2 Identification of restructuring needs

In the privatization process besides non-standard (coupon) method are, above all, used the following standard methods:

- direct sale,

- public vendue,

- public tender.

The properties within funds of national property can be privatized by means of basic methods, as follows:

- by founding of a joint stock company or other commercial company,

- by selling of the enterprises' property or of its part,

- by assignment of the privatized property to the municipalities,

- by assignment of the privatized property for purpose of health and retirement insurance, etc.

\section{References:}

[1] BUČEK A KOL.: Transformácia železníc vo svete, EDIS ŽU v Žiline, 2002

\section{TRENDS IN AIR TRAFFIC CONTROLLERS TRAINING IN UNIVERSITY OF ŽILINA}

The paper describes an applied and planned training structure for training of air traffic controllers in Slovakia in cooperation with the Air Traffic Services of the Slovak Republic. Initial Training consists of basic training and qualification/endorsement training. Initial Training is designed to enable a student to progress to a specialized training in the unit. Operational Training is a training given in the operational work situation and following the institutional training. It comprises Transition Training, pre-On-the-Job Training and On-the-Job Training. Transition Training Phase follows after Initial training during which skills will be developed through 
the use of site-specific simulations. Pre-On-the-Job Training Phase will enhance the development of previously acquired abilities to a high level of achievement. On-the-Job Training is a "live training' where previously acquired skills are further developed under the supervision of a qualified coach in an operational situation.

Basic Training is performed at the University of Žilina and is approved by the Civil Aviation Administration of the Slovak Republic.

After the training conducted at our university the student moves to the Air Traffic Services of the Slovak Republic. The first part of training will ensure that the student is made familiar with site specific items. This is done through Transition Phase and PreOJT Phase.

Then s/he will proceed to On the Job Training, under the coaching of a practicing controller. The result of this training is the working controller and $\mathrm{s} / \mathrm{he}$ continues throughout the lifetime in further training so that standards can be maintained.

The cooperation of the University of Žilina and the Air Traffic Services of the Slovak Republic in the training of air traffic controllers results in a training structure which fully satisfies requirements of Eurocontrol. Basic Training performed at the University gives knowledge to enable a student to progress to qualification/endorsement training at the premises of the Air Traffic Services of the Slovak Republic. This is followed by Operational Training given in the operational work situation. It comprises Transition Training, pre-On-the-Job Training and On-the-Job Training.

\section{References}

[1] Guidelines for Common Core Content and Training Objectives for ATCOs Training (Phase II), HUM.ET1.ST05.DEL02, 1999

[2] Guidelines for common core content and training objectives for air traffic controllers training (phase I) HUM.ET1.ST05.1000GUI-01, 1997

[3] Guidelines for common core content and training objectives for air traffic controllers training (phase II) HUM.ET1.ST05.1000GUI-02,. 2000

[4] European Manual of Personnel Licensing - Air Traffic Controllers, HUM.ET1.ST08.10000-STD-01, 2000

\section{PROJECTS FOR REGIONAL DEVELOPMENT}

The task of public sector is to improve the quality of life of inhabitants. The public sector will be oriented to increase of internal efficiency and to enhancement of immediate intercommunication with public in the future. Public services are often marked by inadequate number of managers, who are able to harmonize political and economic aims, to balance mixture of sources and administrative restrictions, which are the natural part of public sector environment.
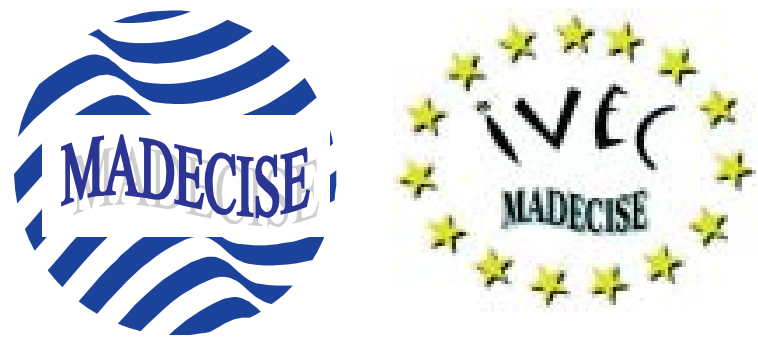

In the frame of the public administration reform in the Slovak Republic and in the frame of integral processes in the European Union (EU, Euro-regions etc.), it is necessary to develop the personal education system on individual levels in public administration and with the development of participating democracy is connected the problem solution in several regions and locations. From these requirements resulted the solution of various projects which are coordinated by the staff of department of communications, at the Faculty of Operation and Economics of Transport and Communications of the University of Žilina: TEMPUS PHARE Institutional Building Project - Managerial Development of Civil Servants (MADECISE) 1999-2002; VEGA Project - Marketing support of regional development; Projects of international scientific-technical cooperation.

In the frame of these projects solution several interesting results were achieved such as creation and realisation of education system for public administration staff in the sphere of EU law in conditions of public administration institutions, EU fiscal policy, international economic and monetary relations, evaluation of fixed assets and companies and several aspects of public management. Further result was a creation of information and educational centre MADECISE - IVEC as an important output to ensure long-lasting growth in collaboration with partners who are participating in the program realization (Fontys Eindhoven, HTW Dresden, Deutsche Telekom, AG, Citta di Motta di Livenza, TU Zvolen, UMB Banská Bystrica and 24 institutions of public administration in the Slovak Republic).

The basis of cross border cooperation projects was given by the agreement among the Regional Office in Žilina, GIG Kato- 
wice, the former Bielsko-Biala Ducal Office, on the basis of which the study: "Program of economic and social activation of cross border areas" was completed.

In the frame of Beskydy Euro-region several marketing researches and international comparisons were carried out. They aimed at methodology development for marketing searching in regions. It is possible to say that from the Euro-regions activities results the following: the socio-cultural aspect of cross border cooperation is a very important basis for higher form of cooperation in the economic sphere. But it is necessary to appreciate and to solve the problem of barriers.

It is possible to identify the barriers in development process of cross border cooperation and they result from several causes, especially from language, cultural, juristic and institutional differences. Although these barriers do not necessarily have to include the area aspect, many of them are clearly showing in the area. The barriers resulted from defined state boundaries or region boundaries. Their basis is connected with defined conditions in the market sphere, international relationships, internal fiscal and monetary policy.

It is important to perceive some differences in the development in the Slovak Republic, Czech Republic and Poland in the last ten years:

- Czech Republic - average living standard and average income are best among these countries,

- Poland - It is a quickly growing country although the total prosperity among population increases very unequally. It has the lowest GDP per citizen,

- Slovak Republic - negative economic period with high unemployment rate, in the sense of Center-European measures.

On the basis of our research we can conclude:

- The main barriers in the Internet commerce development in these countries are related to the Internet level penetration, level of telephone charges, eventually charges for connecting,

- The state of Legislation in e-commerce (although laws about electronic signature are accepted in all of these countries), certain disbelief in on-line commerce or low level of awareness about ecommerce advantages, especially among companies and the rising of internet markets number with low level of offered services.
Initial indicators for valuation of level of Internet trades

Tab. 1

\begin{tabular}{|l|r|r|r|}
\hline Indicator & CZE & POL & SVK \\
\hline Number of Internet trades & 2800 & 800 & 515 \\
\hline Population (in mil. 1998) & 10.3 & 38.7 & 5.4 \\
\hline $\begin{array}{l}\text { GDP per citizen / } \\
\text { in Euro (1998) }\end{array}$ & 12200 & 7800 & 9300 \\
\hline $\begin{array}{l}\text { Penetration of internet / } \\
\text { in \% (2001) }\end{array}$ & 11 & 11 & 7 \\
\hline $\begin{array}{l}\text { Penetration of personal } \\
\text { Computers / in \% (2001) }\end{array}$ & 14 & 7 & 13 \\
\hline $\begin{array}{l}\text { Penetration of HTS / } \\
\text { in \% (2001) }\end{array}$ & 40 & 29 & 32 \\
\hline $\begin{array}{l}\text { Number of Internet trade } \\
\text { per 100000 citizens. }\end{array}$ & 27.18 & 2.07 & 9.53 \\
\hline Number of evaluated trades & 200 & 200 & 200 \\
\hline - percent of total number & 7.14 & 25 & 38.8 \\
\hline - number of functional trades & $170(85 \%)$ & $175(87.5 \%)$ & $165(82.5 \%)$ \\
\hline - number of inaccessible trades & $30(15 \%)$ & $25(12.5 \%)$ & $35(17.5 \%)$ \\
\hline - number of B2C & $29.4 \%$ & $69 \%$ & $71,5 \%$ \\
\hline \multicolumn{1}{|c|}{ B2B } & $4.9 \%$ & $0 \%$ & $3.6 \%$ \\
\hline B2C + B2B & $65.7 \%$ & $31.0 \%$ & $9.1 \%$ \\
\hline
\end{tabular}

\section{References:}

[1] ŠTOFKOVÁ, J. et al.: Marketing support of regions diagnosing. VEGA $1 / 8010 / 01$

[2] Final report, TEMPUS PHARE IB_JEP-14380-1999 MADECISE, 2002

[3] ŠTOFKOVÁ, J. et al:: MVTS SK-PL project Pol'/Slov/01 Methodology of marketing survey of business in cross border region of Beskydy Euro-region

[4] BINDA, J.: Podstawy sieci komputerowych. WSBiF Bielsko Biala, 2003

[5] ŠTOFKOVÁ, J., ACHIMSKÝ, K., ROSTÁŠOVÁ, M., ŠTOFKO, S.: Program of economic and social activation of boundary areas. Žilina University in Žilina, 1998

[6] Collective of authors: Rozwoj Eurergionu Beskidy. Doswiadczenia Oczekiwania-Perspektywy. Materialy konferencyjne, 2002, NR 2, Bielsko-Biala, ISSN 1429-673X 


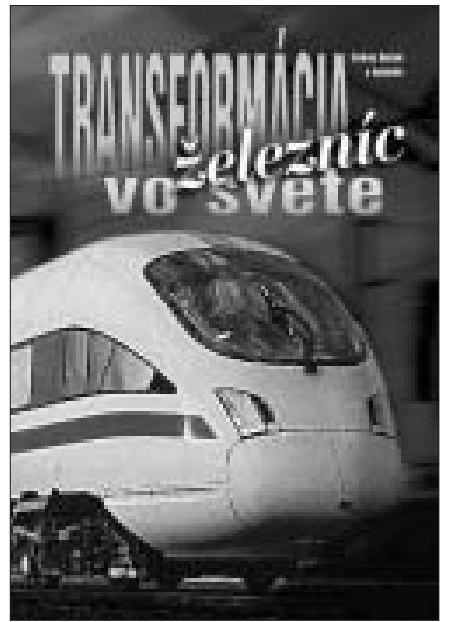

\title{
Transformation of Railways in the World
}

\author{
doc. Ing. Ondrej Buček, PhD. \\ Ing. Anna Tomová, CSc. \\ Ing. Viera Bartošová \\ Ing. Alžbeta Bieliková \\ Ing. Danka Harmanová, CSc. \\ Ing. Darina Chlebíková, CSc.
}

ISBN 80-7100-946-6 EDIS-Publishing House. Žilina University in Žilina 2002

This scientific publication was originated on the basis of investigation of the transformation of railways in the world, namely on the analysis of the situation of 20 exquisite railways. Most thoroughly were analyzed railways in western Europe together with some countries of CEFTA. Experience from Japan, New Zealand, Mexico and Canada was also significant. The analysis dealt with the investigation in these countries as well as with individual steps of railway transformation, probable consequence of which eventuated into privatization in some countries. Thus, the publication evaluates the starting-points of the situation conditions of railways before the implementation of transformation. It was not only the technical situation but mainly the economic profit which led to the necessity of looking for new ways of restructuring and following transformation of railways. This publication was also prepared as a source for the analysis of steps in transformation of the Slovak Railways. This publication as well as its sources, based on extensive predecessing research from 1996, points out the presumptions together with the effects of possible transformation.

\section{Diagnostic Process in Quality Management in Post-offices}

prof. Ing. Tatiana Čorejová, PhD.

doc. Ing. Mária Rostášová, PhD.

Diognosticky postup

vimanazerstve kvally vpozito

\section{ISBN 80-7100-619-X, University of Žilina, 1999}

The monograph is devoted to topical problems of quality diagnosing in the sphere of transport of items. The need of diagnosing and measuring quality of the postal products is determined by several factors and finally it focuses on the main objective that is customer's satisfaction.

The aim of this monograph is to outline the merits of the diagnostic approach in quality management in postal sector and, therefore, it is divided into two parts. The first part is devoted to the terminological and methodical basis of the quality management - to solving the problems as for quality in business practice, paying particular attention to the processes concerning the transport of items. The second part includes methodical directions for using the diagnostic process in the quality management in relation to the appropriate methods for the quality diagnosing in processes of the transport of items. The application of diagnostic approaches, which is proposed in the monograph, offers opportunities for knowing the existent standing of a postal establishment on the market, knowing its own chances of the existing opportunities utilization and it is a primary assumption for specifying reasonable objectives, elaborating an appropriate strategy and its method of realization as well as for long-term development and survival of an establishment.

The monograph is for full-time and part-time students of the University of Žilina, for postgraduate students as well as for scientific and professional staff concerned with quality management problems and quality diagnosing. Its content relates directly to the solution of the scientific grant project VEGA 1/5270/98 "Tools of environment diagnostics in transport of items". 


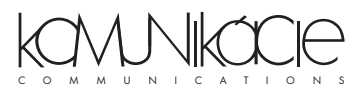

\section{Finances at Post-offices and Telecommunications}

prof. Ing. Jana Štofková, PhD.

Ing. Pavel Kaštánek

doc. Ing. Mária Rostášová, PhD.

doc. Ing. Stanislav Štofko,CSc.

\section{ISBN 80-7100-580-0}

The monograph deals with financial problems of infrastructure sectors. Post-offices and telecommunications belong also to these sectors. It is an invariable fact that sudden development of telecommunications is effected by convergence of telecommunication and information technologies and media. The monograph includes introduction to problems of company finances. A significant part deals with categories of financial decision making of company.

The publication mentions problems of individual methods of estimation of a company value as well as value of corporeal parts of property and it deals with development of legislation of this section before accession of a strategic partner to telecommunications. The monograph elusidates to the reader external and internal sources of financing. Other part deals with the tax system and techniques of tax settlement in telecommunications sphere as well as chosen problems of an optimal tax burden. The essential part of financing is the topic of financial planning as a part of company and strategic planning. A separate chapter is devoted to budgeting as a tool for financial managing of a company. A significant part of the monograph uses financial analysis especially financial ratio indexes in postal and telecommunication companies. The publication is written for internal and external students of Žilina University, PhDstudents, scientific staff dealing with questions of finances and financial management. The monograph includes particularities of post and telecommunications influencing management of these infrastructure sectors. 
